\title{
Teachers' Views on Classroom Infrastructure Facilities in Special Education Integration Program in Primary School
}

\author{
Norwahidah Mihat, Mohd Hanafi Mohd Yasin, Mohd Mokhtar Tahar \\ Universiti Kebangsaan Malaysia, Malaysia \\ E-mail : norwahidahmihat@gmail.com
}

\begin{abstract}
The main aim of the research is to ensure effective lesson and produce best impact in classroom by providing conducive and comfortable condition. The objective of this research is to obtain Special Education Teachers' views regarding the Special Education Integration Program (PPKI) in primary school in Seremban, Negeri Sembilan. This research was conducted quantitatively based on Maslow's hierarch needs theory. A random sampling method is used in gathering the research data involving 137 special education primary school teachers. The research instrument is an adaptation from the questionnaire of the special education infrastructure needs in Malaysia. The data were analyzed descriptively. The findings showed that the level of special education classroom facilities special education teachers' views is at moderate level. The research concludes that improvements in infrastructure facilities need to be done to meet the UDL model requirements for the convenience of special education students.
\end{abstract}

Keywords: teachers' views, classroom infrastructure facility, primary school

\section{INTRODUCTION}

The Malaysian Education Development Plan (MEDP) (2013-202), has outlined 11 shifts in the transformation of the nation's education system to ensure that the entire individual level of engagement in state education is not left behind in the changes. In the first shift, MEDP emphasizes equality of access to international quality of education. This is in line with one of the educational aspirations of the country, which is to bridge the educational gap between the location, the level of socioeconomics and ability of the student itself. The goal is to ensure students to have equal opportunity to excel, including special education students in gaining access, equity and quality in education.

Like the Biwako Declaration (2003-2012) states that the government should provide suitable infrastructure that can be used by Individuals with Special Ability. Therefore, the Ministry of Women, Family and Community Development has taken the initiative by establishing a Special Ability's Action Plan 2016-2022 with the aim of empowering and celebrating Special Ability's individuals in society. The initiative is to upgrade the infrastructure and equipment at all schools and Higher Educational Institutes to be handicappedfriendly by using Universal Design (UD) and Universal Design for Learning (UDL).

An article on the website of Spring Independent School District, Texae explained that UDL is an adaptation from UD concept found in architecture that removes barriers to provide access for all users. UDL in classroom removes barriers in curriculum and instruction by providing flexible opportunities for all students, thus increasing engagement.

Referring to McLeod (2007), Maslow suggested that human needs could be put into five levels. From the bottom of the hierarchy upwards, the needs are: physiological, safety, love and belonging, esteem and self-actualization. At the first stage this physiological requirement is the most basic requirement i.e. the need for food and drink. This requirement is important for every living organism, notably human. Human would move to the next level once the first level of needs has been fulfilled which is Safety Needs where human need to feel safe, comfortable and secure. This is a matter of concern by the relevant parties in meeting the needs of students with special needs learning problems to feel comfortable and conducive in following the process of teaching and facilitating in the classroom, and generally in school.

Preeti and Kiran (2012), mentioned that to ensure the teaching and facilitating process goes well and to produce the best impact and effect, the classroom must always be accommodated in a comfortable and conducive environment for the students. Beaton et al. (2000), stated that the place where a pupil with special abilits studiey would influence their behaviour, achievement and social growth. Therefore, a conducive classroom not only produces excellent students but also provide guidance on the pupil's behaviour.

This research aims to look at the level of SEIP classroom infrastructure facilities from the perspective of primary school SEIP teachers in Seremban Negeri Sembilan. 
Universal Design for Learning in classroom UDL serves as a framework of teaching by removing obstacles in the classroom and offers flexibility in how students learn and submit information.

\begin{tabular}{ll}
\hline & \multicolumn{1}{c}{ RULES } \\
\hline - & The main chart \\
- & The checklist \\
- & Electronic warnings \\
- & Organizational charts \\
- & Manipulative \\
- & Physical arrangement \\
- & Template \\
- & Visual reech requirements \\
\hline & $\quad$ CONTACTS \\
\hline
\end{tabular}

- Using self-reflection

- $\quad$ Give feedback

- Acknowledging student voices

- Using active diagrams

- Explain the purpose of the activity

- Learn the related culture

- Making partnerships between peers

- $\quad$ Provide options to students

- $\quad$ Students make their own goals

\section{ACTION AND EVIDENCE}

- Using web applications

- Using Text-to-Speech technology

- Provide various examples

- Transaction of various types of media for communication

- Provides virtual manipulative and concrete

- Provides alternative actions for pencils / pencils

- Using various tools for construction and composition

- Using the Scaffolding technique that gradually improves the student's independence

- $\quad$ Drive the goal setting, plan, and monitor progress

\section{METHOD}

This research was conducted quantitatively, and the research data was obtained from the questionnaire. The population of the research was comprised of 220 primary school SEIP teachers around the district of Seremban, Negeri Sembilan. Based on Krejie, Robert V. Morgan Daryle W (1970), a total of 137 teachers of SEIP were taken as the sample research through stratified random sampling technique.
Table 1. Mean Value and Standard Deviation Level Infrastructure Facilities Level of Special Education Integration Program

\begin{tabular}{|c|c|c|c|}
\hline & Mean & SD & Level \\
\hline $\begin{array}{l}\text { Special Education Pro- } \\
\text { gram Management Infor- } \\
\text { mation }\end{array}$ & 3.21 & 0.60 & Medium \\
\hline $\begin{array}{l}\text { Special Education Inte- } \\
\text { gration Program Loca- } \\
\text { tion }\end{array}$ & 3.12 & 0.61 & Medium \\
\hline $\begin{array}{l}\text { Special Education Inte- } \\
\text { gration Program Physical } \\
\text { Condition }\end{array}$ & 2.56 & 0.78 & Medium \\
\hline $\begin{array}{l}\text { Special Education Pro- } \\
\text { gram Integration Facili- } \\
\text { ties }\end{array}$ & 2.84 & 0.45 & Medium \\
\hline $\begin{array}{l}\text { Special Education Inte- } \\
\text { gration Program Class- } \\
\text { room Information }\end{array}$ & 3.22 & 0.42 & Medium \\
\hline $\begin{array}{l}\text { Equipment and Furniture } \\
\text { for Special Education In- } \\
\text { tegration Program }\end{array}$ & 3.00 & 0.45 & Medium \\
\hline $\begin{array}{l}\text { Overall (Classroom In- } \\
\text { frastructure Facility Spe- } \\
\text { cial Education Integra- } \\
\text { tion Program) }\end{array}$ & 2.99 & 0.30 & Medium \\
\hline
\end{tabular}

The instrument of this research was a questionnaire adapted from the research of Infrastructure Sufficiency Study on Special Education Integration Program in Malaysia developed by Yasin et al. (2013) to measure the Infrastructure Sufficiency Program of Special Education Integration in Malaysia and endorsed by two experts. The 5-point Scale was used in the questionnaire. In addition, respondents were asked to answer an open question to suggest a suitable SEIP infrastructure in their schools. Questionnaire data was analysed using SPSS and was interpreted inoffensively, while data from open question was analysed descriptively.

\section{FINDINGS AND DISCUSSION}

\section{Finding}

Through Table 1, the survey on the level of Education Infrastructure in Special Education Primary School in Seremban, Negeri Sembilan shows that the mean $=2.99, \mathrm{SD}=0.30$ in the view of the Special Education teacher is at moderate level. In this research, the level of the Special Education Classroom Infrastructure Facility is measured by 6 constructs i.e: 
(1) Management Information of the Special Education Program; (2) Location of the Special Education Integration Program; (3) Physical Condition of Special Education Integration Program; (4) Facilities of the Special Education Integration Program; (5) Classroom Information of the Special Education Integration Program, and; (6) Equipment and Furniture of the Special Education Integration Program.

Table 1 shows that the score of Management Information of the Special Education Program (mean=3.21, $\mathrm{SD}=0.60$ ), Locations of the Special Education Integration Program (mean=3.12, SD=0.61), Physical Condition of the Special Education Integration Program (mean= 2.56, $\mathrm{SD}=0.78$ ), Facility of the Special Education Integration Program (mean $=.84$, $\mathrm{SD}=0.45$ ), Classroom Information of the Special Education Integration Program (mean $=3.22, \mathrm{SD}=0.42$ ), and Equipment and Furniture of the Special Education Integration Program (mean=3.00, $\mathrm{SD}=0.45$ ) among Special Education teachers are at a modest level.

Through Table 1, it can also be seen from the six constructs studied that the construct of Condition in the Special Education Integration Program Physical was low compared to 5 other constructs, mean reading $=$ 2.56, and $\mathrm{SD}=0.78$.

This is further proven by an open question which revealed that $50 \%$ of the respondents requested to have additional SEIP classrooms or existing space at school to provide conducive space for special needs students. Other proposals stated that SEIP should be provided with special buildings or its own building only for special education students to create a comfortable and conducive environment, but this is contrary to the UDL model concept that integrates special education students with ordinary students. Additionally, there is also a proposal to provide ramp and covered ramps for wheelchairs and toilets that are connected to the main chamber of SEIP classrooms.

\section{Discussion}

Guardino and Fullerton. (2010) states that disturbing behavior is attributable to an unconducive and sophisticated classroom condition, teachers can not properly communicate the process of teaching and facilitating. Referring to Azizah (2011) and Loreman, Deppeler, \& Harvey (2005), some things to consider in relation to infrastructure facilities in schools are: (1) Ramp on every staircase; (2) Door position and suitability of speed when the door is open and close; (3) Furniture settings, obstacles in the classroom such as games, bags, rugs, toys and sports equipment; (4) Timetable, benches and shelf's height; (5) Lighting, The student's position in the line for unclear vision; (6) Violence; (7) Access to sinks and another special classroom equipment; (8) Access to drinking water fountain; (9) Access to other areas of the school such as other buildings, sports fields, playgrounds; (10) Security from danger.

The availability of suitable classroom infrastructure and facilities has been an important recommendations in several previous researches. Hanafi et al. (2010) found in his research that almost half of the respondents claimed the lack of basic facilities in the classroom. He suggested that there should be a clear standard for this. In line with this idea, Heiman (2001) also argued that for larger classes consisting of more students, limited facilities and study materials caused some obstacles in the teaching and learning activities.

In relation to the facilities that are mentioned earlier, Oluremi (2015) proposed the availability of resource room which is equipped with modern teachings aids for students with special needs. Sheffler (2009) also mentioned that decorating classrooms with colors to create warm feelings can help promote a sense of comfort and security.

However, it is important to notice that classroom facilities are not the only factor to determine the success of inclusive education. Tanyi (2016) found that teachers attitudes in inclusive classrooms have no significant impacts with the available infrastructure. Even so, Tanyi agreed that good quality and relevant infrastructure can enhance teachers' pedagigic skills.

\section{CONCLUSIONS}

From the findings, the level of existing classroom infrastructure facilities in SEIP primary school in Seremban was at moderate level. This also shows that the infrastructural facilities in each SEIP in Seremban are less likely to follow the features described in the Universal Design for Learning model aimed at eliminating existing obstacles to enable students with special needs to access every facility and angle in the classroom.

One of the suggestions that can be highlighted for improving the infrastructure level of the SEIP classrooms of primary school is creating an additional classroom to provide a conducive and comfortable space for the process of teaching and facilitating to function properly. Authorities such as the Ministry of Education, State Education Department, District Education Office and School Administrator who manage the provision and renovation of infrastructure facilities shall provide all requirements that are needed to support the learning process. Among other initiatives that can be highlighted to measure the level of infrastructure facilities for the SEIP classroom is also to create special needs childrenfriendly infrastructure standards school. 
Every student needs to feel comfortable without any obstacle in acquiring knowledge in school. The availability of infrastructure facilities in schools is a motivation and encouragement for students to learn as well as for teachers in delivering the process of teaching and facilitating in. At the same time, PPM 2013-2025 can be realized to ensure that all levels of the individual receive quality education, and nothing is left behind in the changes.

\section{REFERENCES}

Beaton, D. E., Bombardier, C., Guillemin, F., \& Ferraz, M. B. (2000). Guidelines for the process of crosscultural adaptation of self-report measures. Spine, 25(24), 3186-3191.

Sheffler, J. L. (2009). Creating a warm and inclusive classroom environment: Planning for all children to feel welcome. Electronic Journal for Inclusive Education, 2(4), 41-13

Heiman, T. (2001). Inclusive schooling-middle school teachers' perceptions. School Psychology International, 22(4), 451-462.

McLeod, S. (2007). Maslow's hierarchy of needs. Simply psychology, 1.

Guardino, C. A., \& Fullerton, E. (2010). Changing behaviors by changing the classroom environment. Teaching exceptional children, 42(6), 8-13.
Yasin, M. H. M., Toran, H., Tahar, M. M., Bari, S., Ibrahim, S. N. N., \& Zaharudin, R. (2013). Bilik Darjah Pendidikan Khas Pada Masa Kini Dan Kekangannya Terhadap Proses Pengajaran (Current Special Education Classroom And Its Limitations Towards Teaching Process). Asia Pacific Journal of Educators and Education, 28, 1-9.

Azizah, N. (2011). Managing Inclusive School: What Should School Provided to Help Students with Special Needs. Jurnal Pendidikan Khusus.

Preeti, T., \& Kiran, U. V. (2012). Infrastructural Facilities for Differently Abled Students-A Comparative Study of Government and Non-Government Institutions. International Research Journal of Social Sciences, 1(3), 21-25.

Loreman, T., Deppeler, J., \& Harvey, D. (2005). Inclusive Education: a Practical Guide to Supporting Diversity in the Classroom. London: RoutledgeFalmer

Yasin, M. H. M., Toran, H., Tahar, M. M., \& Bari, S. (2010). Teacher's perspective on infrastructure of special education's classroom in Malaysia. Procedia-Social and Behavioral Sciences, 9, 291294.

Oluremi, F. D. (2015). Inclusive Education Setting in Southwestern Nigeria: Myth or Reality?. Universal Journal of Educational Research, 3(6), 368-374.

Tanyi, M. E. (2016). Pedagogic Barriers in Cameroon Inclusive Classrooms: The Impact of Curriculum, Teachers' Attitudes and Classroom Infrastructures. Journal of Education and Practice, 7(18), 210-221. 